\title{
The in vitro toxicity evaluation of halloysite nanotubes (HNTs) in human lung cells
}

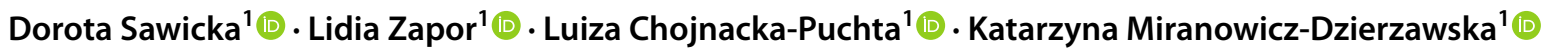

Received: 28 January 2020 / Revised: 3 August 2020 / Accepted: 21 August 2020 / Published online: 13 October 2020

(c) The Author(s) 2020

\begin{abstract}
Halloysite nanotubes (HNTs) have been increasingly used in many industrial and biomedical fields. Therefore, the assessment of risk and consequences of exposure to HNTs is very important to better protect human safety. This study aims to investigate the short- (24 or $72 \mathrm{~h}$ ) and long-term (7 days) cytotoxic effects of HNTs at doses 10-200 $\mu \mathrm{g} / \mathrm{mL}$ on human alveolar carcinoma epithelial cells (A549) and human bronchial epithelial cells (BEAS-2B). The effect of HNTs on cell viability, apoptosis, cell proliferation, oxidative/antioxidative status and cell morphology was evaluated. Our results showed that cytotoxicity of HNTs is dependent on dose, cell model and time of exposure. During the time of exposition toxic effects were intensified. To the best of our knowledge, this is the first study to use holo-tomographic microscopy (HTM) to visualise changes in cell morphology due to exposure from HNTs. We observed cells contraction, changes in the size and shape, cell surface folding and cytoplasmic vacuolization, peripheral arrangement of cell nuclei and even increase number of nucleus, which undoubtedly confirmed cytotoxic effect of HNTs at low doses $(5 \mu \mathrm{g} / \mathrm{mL}$ and $25 \mu \mathrm{g} / \mathrm{mL})$. Our results demonstrated that HTM technique provides a new insight into the assessment of HNTs toxicity. Further studies with different cell models are recommended to assess the toxic effect of HNTs on whole human body.
\end{abstract}

Keywords Cytotoxicity $\cdot$ Halloysite nanotubes $\cdot$ Holo-tomographic microscopy $\cdot$ Lung cells

\section{Introduction}

Halloysite $\left(\mathrm{Al}_{2} \mathrm{Si}_{2} \mathrm{O}_{5}(\mathrm{OH})_{4} \cdot n \mathrm{H}_{2} \mathrm{O}\right)$ is two-layered aluminosilicate with a unique hollow tubular structure and high aspect ratio. The size of halloysite nanotubes (HNTs) varies within $1-15 \mu \mathrm{m}$ and $10-150 \mathrm{~nm}$ of inner diameter. HNTs occurs naturally, and it is chemically similar to another clay mineral - kaolin [1,2]. The characteristics feature, such as unique tubular structure, high aspect ratio, nanoscale lumens, cheap and abundant availability make this nanomaterial useful in many applications [3]. HNTs have huge potential in biomedicine, including drug and gene delivery vesicles, tissue engineering, bone implants, ultrasound contrast agents, teeth

Electronic supplementary material The online version of this article (https://doi.org/10.1007/s43188-020-00062-1) contains supplementary material, which is available to authorized users.

Dorota Sawicka

dosaw@ciop.pl

1 Central Institute for Labour Protection, National Research Institute, Czerniakowska 16, 00-701 Warsaw, Poland fillers, cancer and stem cells isolation and cosmetics [4-8]. Furthermore, it is usually used in the fabrication of highquality ceramic white-ware and for preparing polymer-based composites (as nanofiller), remediation of environmental contaminants, storage of molecular hydrogen, catalytic conversion and processing of hydrocarbons, as nano additives for pigments and many others [9-12].

Similarity of HNTs tubular structure to carbon nanotubes (CNTs) may potentially cause the same toxicity such for CNTs, which include pulmonary inflammation and acute phase response following pulmonary exposure and even tumour changes in the human respiratory system [13-16]. Taking into consideration many applications of HNTs, the evaluation of HNTs toxicity is crucial for workers safety. The information on toxicological effects of HNTs on human health is limited [1], therefore, there is an emerging need to investigate the potential risk and consequences of effects of exposure to HNTs.

This study evaluates the effect of HNTs at doses $10-200 \mu \mathrm{g} / \mathrm{mL}$ on cell viability and apoptosis using human alveolar carcinoma epithelial cells (A549) and human bronchial epithelium cells (BEAS-2B) after short- (24 or $72 \mathrm{~h}$ ) 
or long-term (7 days) exposure to HNTs. The ability of cells to proliferate and oxidative/antioxidative status were also examined. We also observed the morphological changes in cells exposed to low doses of HNTs ( $5 \mu \mathrm{g} / \mathrm{mL}$ and $25 \mu \mathrm{g} / \mathrm{mL}$ ) using the holo-tomographic microscopy (HTM).

\section{Materials and methods}

\section{Preparation and characterisation of HNTs}

The morphology of HNTs (Sigma-Aldrich, St. Louis, MO, USA) was characterised using scanning electron microscopy (SEM, Zeiss Ultra Plus, Germany). The particle size and size distribution of HNTs were analysed using the nanoparticle tracking analysis (NTA) (NS500, Malvern Instruments, Amesbury, UK). The HNTs were suspended in culture media used for culturing BEAS-2B cells or for A549 cells. The suspensions were sonicated in an ice bath at high energy level of $420 \mathrm{~J} / \mathrm{cm}^{3}$ (60 s with amplitude 90\%) (Sonica Q 700, Qsonica LLC, USA) and stirred for $1 \mathrm{~min}$ to ensure homogeneity before measurements at three time points: after $5 \mathrm{~min}, 24 \mathrm{~h}$ and $48 \mathrm{~h}$. Such prepared suspensions were loaded into the laser module sample chamber and viewed in close proximity to the optical element. Particles in the liquid sample which passed through the beam path were seen as small points of light moving rapidly under Brownian motion, allowed information on particle properties. Particles moves were registered by CCD camera, due to scattering of laser light beam. Recorded video capture enabled latter particles identification and movement route analysis. Thanks to simultaneous video-tracking of single particles we obtained highresolution data about particle size distribution, such as mean size and mode size. The "mean value" was the arithmetic mean of particle size distribution and the "mode value" represents the particle size most commonly found in the particle size distribution. The data was captured and analysed using the software NTA 2.3 (Malvern). The same procedure of preparation HNTs was applied to all cytotoxicity assays.

\section{Cell culture and treatment}

The A549 cells (CCL185) and BEAS-2B cells (CRL-9609) were obtained from American Type Culture Collection (ATCC, LGC Standards, UK). The A549 cells were cultured as a monolayer in an F12K medium (Gibco, Invitrogen, Carlsbad, CA, USA) supplemented with $10 \%$ foetal bovine serum (FBS, Gibco) and 1\% antibiotic-antimycotic (SigmaAldrich) in sterile tissue culture flasks (Nunc, Roskilde, Denmark). BEAS-2B cells were cultured in the LHC-9 serum-free medium (Thermo Fisher Scientific MA, USA) containing 1\% antibiotic-antimycotic (Sigma-Aldrich). Both cell lines were grown at $37{ }^{\circ} \mathrm{C}$ and in a humidified atmosphere $\left(5 \% \mathrm{CO}_{2}\right)$. The cells were passaged before reaching $90 \%$ confluence. To detach cells from the culture plates, $0.25 \%$ trypsin-EDTA (Gibco) was used. Additionally, cells were screened for Mycoplasma sp. infection using MycoAlert ${ }^{\mathrm{TM}}$ PLUS Mycoplasma Detection Kit (Lonza, Walkersville, Inc.).

\section{Cytotoxicity assays of HNTs}

\section{MTT assay}

The in vitro cytotoxicity of HNTs was evaluated using MTT assay as described by Mossman [17]. This assay is based on measuring mitochondrial dehydrogenase activity living cells. In brief, BEAS-2B cells or A549 cells were seeded at a density of 10,000 cells/well in a 96-well culture plate (Nunc) and cultured overnight $\left(37^{\circ} \mathrm{C}, 5 \% \mathrm{CO}_{2}\right)$. After this period, non-attached cells were aspirated followed by the addition of HNTs suspension at different concentrations (10-200 $\mu \mathrm{g} / \mathrm{mL}$ ). The plates were then incubated for 24 or $72 \mathrm{~h}$. Then, the medium with HNTs was removed and cells were washed with phosphate buffer saline (PBS) (Gibco). Subsequently, the medium containing MTT (3-(4.5 dimethylthiazol-2-yl)-2.5 diphenyltetrazolium bromide, $5 \mathrm{mg} / \mathrm{cm}^{3}$, Sigma-Aldrich) was added and the plates were incubated for $3 \mathrm{~h}$ and observed until a purple coloured formazan product was formed. This product was dissolved in dimethyl sulphoxide (Gibco) and plates were shaken. Then the absorbance was measured at 570/620 nm using SYNERGY 2 (BioTek Instruments, Inc.) microplates reader. Cytotoxicity tests were performed in at least three independent replications. Based on the absorbance values obtained in MTT test, the viability ratio of cells exposed to the different concentration of HNTs, i.e. the percentage of viable cells compared to control was calculated, followed by the calculation of concentrations of HNTs that reduced cell viability by $50 \%$ compared to control $\left(\mathrm{IC}_{50}\right)$.

\section{Clonogenic assay}

Clonogenic assay also known as colony-forming efficiency assay (CFEA) is based on the ability of a single cell to grow into a colony [18]. A colony is defined to consist of at least 50 clones of one cell (which corresponds to six mitotic divisions). This test detects the number of cells that retained the capacity for producing a large number of progenies after HNTs treatment [19].

The clonogenic assay was conducted according to the procedure described by Franken et al. [20] and adapted from Kruszewski et al. [21]. Briefly, cells in the exponential growth phase (BEAS-2B cells or A549 cells) were harvested and seeded in Petri dish $60 \times 15 \mathrm{~mm}\left(21 \mathrm{~cm}^{2}\right.$ ) (Iwaki Cell Biology, Japan) at a density 500 cells/dish in $5 \mathrm{~mL}$ of 
medium containing HNTs in appropriate concentrations. Each experiment was performed at least in three independent replicates. Cells were exposed to HNTs $(25-200 \mu \mathrm{g} /$ $\mathrm{mL}$ ) for 7 days. After this period, the medium was removed, and cells were washed with PBS. Then, colonies were fixed with ethanol (Sigma-Aldrich), stained with Giemza solution (0.4\%, Sigma- Aldrich) and counted using a stereomicroscope (IUL, Spain). The plating efficiency (PE) and surviving fraction (SF) was calculated, as below:

$\mathrm{PE}=$ (number of colonies formed/number of cells seeded $).$

$\mathrm{SF}=$ (number of colonies formed after treatment/

number of cells seeded $\times$ PE).

The PE ratio for A549 and BEAS-2B cells calculated from three independent experiments was above 0.6.

\section{TOS/TAS assay}

The total oxidative status (TOS) of cells was determined using the PerOx (TOS/TOC) kit (Immundiagnostic AG, Germany), that measures a total level of lipid peroxides in cells. The total antioxidative status (TAS) of cells was determined in the reaction of antioxidants with a pre-defined amount of exogenous hydrogen peroxide $\left(\mathrm{H}_{2} \mathrm{O}_{2}\right)$ using the ImAnOx (TAS/TAC) kit (Immundiagnostic AG). Both tests were performed according to the manufacturer's protocols. In brief, BEAS-2B cells or A549 cells were seeded in 96-well microplates and exposed to HNTs ( 100 and $200 \mu \mathrm{g} / \mathrm{mL}$ ) for $24 \mathrm{~h}$. Then, the cells were washed twice with $100 \mu \mathrm{l}$ of PBS (Gibco) and lysed by freezing at $-80{ }^{\circ} \mathrm{C}$ (in the three thaw/ freeze cycles). Before the evaluation of the oxidative/antioxidative status, cell lysates were sonicated for $30 \mathrm{~min}$ and then centrifuged $(10.000 \times g$ for $5 \mathrm{~min})$. The absorbance was measured at the wavelength of $450 \mathrm{~nm}$ using SYNERGY 2 microplates reader (BioTek Instruments). Each experiment was performed in at least three independent replications. The obtained values were converted to $1 \mathrm{mg}$ of protein in the sample.

\section{Caspase $3 / 7$ assay}

The caspase 3/7 activity was evaluated using an automated in-incubator fluorescence microscope IncuCyte S3 (Live-Cell Analysis System, Sartorius, Michigan, MI, USA). After labelling cells with reagent, this system allows the determination of active caspase 3/7, which is expressed in apoptotic cells. The inert, reagent freely crosses the cell membrane, and after cleavage by caspase 3 , releases a green DNA-binding dye. The green fluorescence of the cleaved substrate can be measured at an excitation maximum of $500 \mathrm{~nm}$ and an emission maximum of $530 \mathrm{~nm}$.

BEAS-2B cells or A549 cells were seeded at a density of 10,000 cells per well in 96-well plates (Nunc) and incubated overnight at $37{ }^{\circ} \mathrm{C}$ in a humidified atmosphere $\left(5 \% \mathrm{CO}_{2}\right)$. Next, cells were exposed to different concentrations of HNTs (10-200 $\mu \mathrm{g} / \mathrm{mL}$ ) for 24 or $48 \mathrm{~h}$. Subsequently, we replaced medium with fresh medium containing $1 \mathrm{x}$ IncuCyte Caspase- 3/7 Apoptosis Assay Reagent (Sartorius). Before start scanning, plates were incubated $\left(37^{\circ} \mathrm{C}, 5 \% \mathrm{CO}_{2}\right)$ for $15 \mathrm{~min}$. As a positive control we used cells treated with staurosporine ( $37 \mathrm{nM}$, Sigma-Aldrich). At each time point, five images were taken per well in both brightfield and FITC channels. Images were analysed for the number of green objects (fluorescing cells) per well by the algorithm in the IncuCyte S3 Software (v2018B). Each experiment was performed in at least three independent replications.

\section{Visualisation of morphological changes in exposed cells via HTM}

For the preparation of samples, BEAS-2B cells or A549 cells were seeded into 35-mm culture dishes (IBIDI, Gräfelfing, Germany) at a density 20,000 cells/dish and incubated for $24 \mathrm{~h}$. Then, cells were treated with HNTs at doses 5 and $25 \mu \mathrm{g} / \mathrm{mL}$ and incubated for 24 or $72 \mathrm{~h}$. The dishes containing untreated cells (control) or exposed cells were placed on the tomographic microscope (3D Cell Explorer, Nanolive S.A., Lausanne, Switzerland) and three-dimensional tomographic images (z-stacks) were created. Further, post-processing steps such as background reduction and contrast enhancement were applied to the final figures using STEVE software (Nanolive).

\section{Statistical analysis}

Statistical analysis was carried out using the Statistica, version 7.1. The $\mathrm{IC}_{50}$ values obtained based on the analysis of a series of dose-response curves were evaluated using non-linear regression analysis at 95\% confidence interval (concentrations reducing cell viability by $50 \%$ as compared with the control). CFEA, NTA results, activity of caspase $3 / 7$ and TOS/TAS data were analysed using Student's $t$-test. A value of $p<0.05$ indicates a statistically significant difference. The data were presented as the mean \pm standard deviation (SD).

\section{Results}

\section{Characterisation of HNTs}

The scanning electron microscopy (SEM) images were carried out to characterise the morphology and detailed structure of HNTs. As illustrated in Fig. 1, the SEM image 
analysis confirmed tubular morphology of HNTs with length $>1000 \mathrm{~nm}$ and diameter circa $100 \mathrm{~nm}$. The NTA analysis showed that after $24 \mathrm{~h}$, diameters of nanotubes were different in LHC-9 medium and F12K medium containing 10\% FBS. After $48 \mathrm{~h}$, we observed decrease in diameters of nanotubes in both media (Fig. 2). The mode values obtained after $24 \mathrm{~h}$, indicated a large share of nanotubes below $100 \mathrm{~nm}$ in the $\mathrm{F} 12 \mathrm{~K}$ medium supplemented with $10 \%$ FBS compared with LHC-9 medium.

\section{Cell cytotoxicity assays}

\section{MTT assay}

We analysed the cytotoxicity profile HNTs on A549 and BEAS-2B cells using MTT assay and evaluated cytotoxicity based on the $\mathrm{IC}_{50}$ values. The results showed that HNTs cytotoxic potency was dependent on dose, cell model and time of exposure. After $24 \mathrm{~h}$ of exposure, the $\mathrm{IC}_{50}$ of HNTs in A549 and BEAS-2B cells was $152 \pm 6.4 \mu \mathrm{g} / \mathrm{mL}$ and $>400 \mu \mathrm{g} / \mathrm{mL}$ (extrapolated value), respectively. However, in $\mathrm{IC}_{50}$ values decreased to $49 \pm 3 \mu \mathrm{g} / \mathrm{mL}$ and $45.1 \pm 8 \mu \mathrm{g} /$ $\mathrm{mL}$, respectively, in A549 and BEAS-2B cells after $72 \mathrm{~h}$ of exposure (Fig. 3a, b).

\section{Clonogenic assay (CFEA)}

As shown in Fig. 4, HNTs to significantly affected the clonogenic survival and cell proliferation in a dose-dependent manner after 7 days of exposure. After exposing A549 cells to HNTs at dose 50-200 $\mu \mathrm{g} / \mathrm{mL}$, we observed a significant difference in SF value compared with control. The ability to

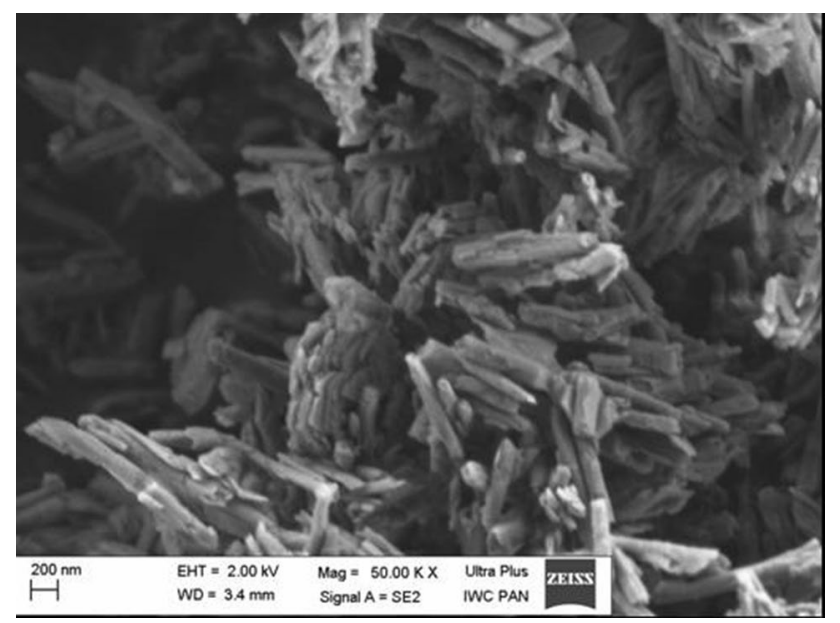

Fig. 1 The characterisation of HNTs. The morphology of HNTs was characterised using scanning electron microscopy (SEM). Magnification and scale are presented on the image

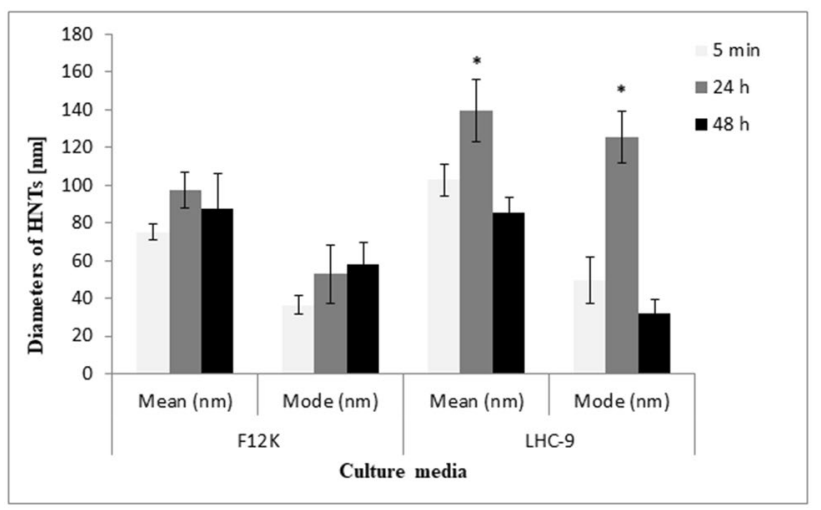

Fig. 2 Analysis of HNTs size distribution. The diameters of the HNTs were measured in the F12K containing $10 \%$ FBS or LHC-9 media after $5 \mathrm{~min}, 24$ and $48 \mathrm{~h}$ using. The graph represents highresolution data about particle size distribution, such as mean size and mode size. Data represent the mean and mode value \pm SD. *Significant differences at $p<0.05$

form colony significantly decreased in BEAS-2B cells after exposure to HNTs at doses $25-200 \mu \mathrm{g} / \mathrm{mL}$ (Fig. 4).

A

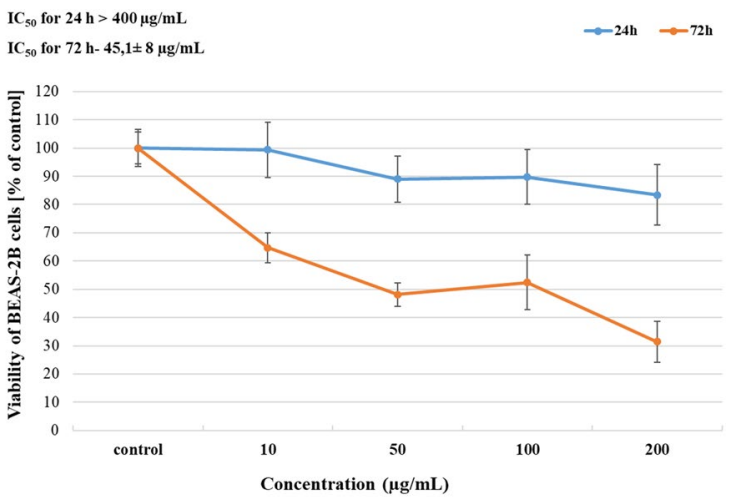

B

$\mathrm{IC}_{50}$ for $72 \mathrm{~h}-49 \pm 3 \mu \mathrm{g} / \mathrm{mL}$

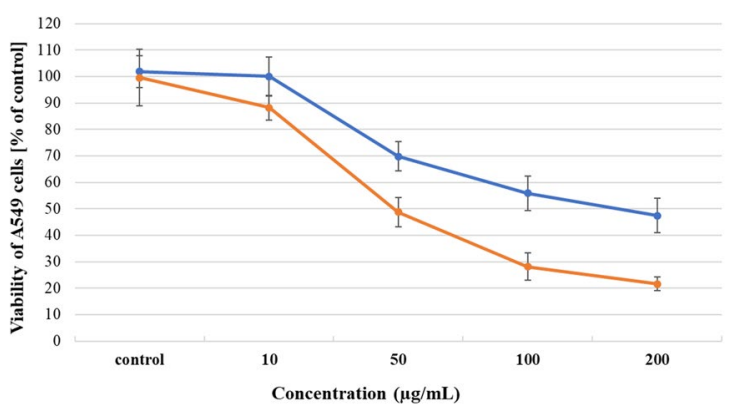

Fig. 3 Analysis of HNTs cytotoxicity. The BEAS-2B cells (a) and A 549 cells (b) were examined by MTT assay after 24 and $72 \mathrm{~h}$ of exposure to HNTs $(10-200 \mu \mathrm{g} / \mathrm{mL})$. Data are presented as the mean \pm SD 


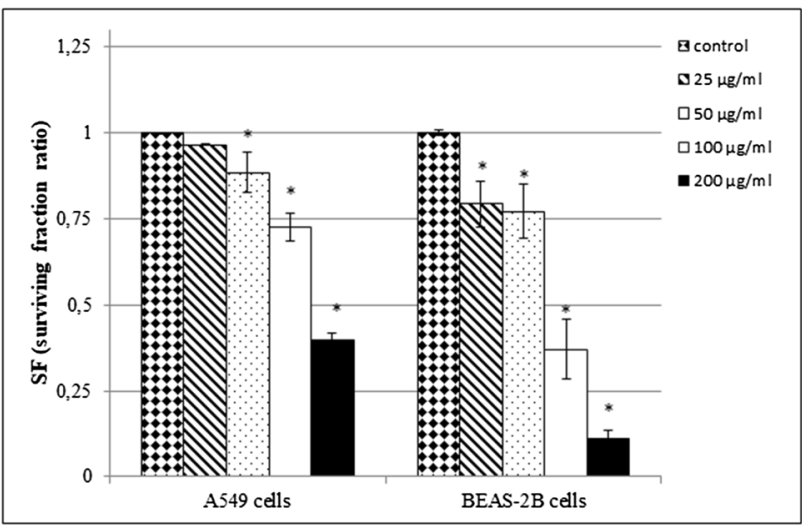

Fig. 4 The ability of A549 or BEAS-2B cells to form colonies after exposure to HNTs. The cells were treated with different concentrations of HNTs $(25-200 \mu \mathrm{g} / \mathrm{mL})$ for 7 days. Data represent the mean \pm SD. *Significantly different from untreated control $(p<0.05)$

\section{Assessment of total oxidative/antioxidative status (TOS/ TAS) of cells exposed to HNTs}

The total oxidative and antioxidative status (TOS/TAS) of the cells exposed to HNTs (100-200 $\mu \mathrm{g} / \mathrm{mL})$ after $24 \mathrm{~h}$ is presented in Fig. 5a, b. In exposed BEAS-2B cells, we did not observe significant changes in the TOS/TAS level compared with the control (Fig. 5a). However, we noticed a slight increase in TAS level after exposure cells to $200 \mu \mathrm{g} /$ $\mathrm{mL}$ of HNTs. The change in TOS/TAS level in A549 cells was dose dependent. We observed an increase in TOS in A549 cells exposed to HNTs at concentration $100 \mu \mathrm{g} / \mathrm{mL}$, but it was accompanied by an increase in TAS. The TAS level after exposure A549 cells to $200 \mu \mathrm{g} / \mathrm{mL}$ of HNTs was higher than TOS (Fig. 5b).

\section{Caspase $3 / 7$ assay}

We determined the activity of caspase $3 / 7$ in BEAS-2B cells or A549 cells using IncuCyte S3 after 24 or $48 \mathrm{~h}$ of treatment with HNTs $(10-200 \mu \mathrm{g} / \mathrm{mL})$ and $37 \mathrm{nM}$ of staurosporine (positive control). In both cells, we observed an increase in the number of apoptotic cells in a dose- and time-dependent manner. Compared with negative control (untreated cells), the number apoptotic A549 cells significantly increased after 24 or $48 \mathrm{~h}$ of treatment with HNTs $(50 \mu \mathrm{g} / \mathrm{mL}$ ) (Fig. $6 \mathrm{~b}$, d). The caspase $3 / 7$ activity in BEAS-2B cells significantly dependent on $24 \mathrm{~h}$ of exposure on $100 \mu \mathrm{g} / \mathrm{mL}$ of HNTs. We observed increase number of apoptotic BEAS-2B cells after $48 \mathrm{~h}$ of exposure on HNTs in doses from $50 \mu \mathrm{g} / \mathrm{mL}$ (Fig. 6a, c).

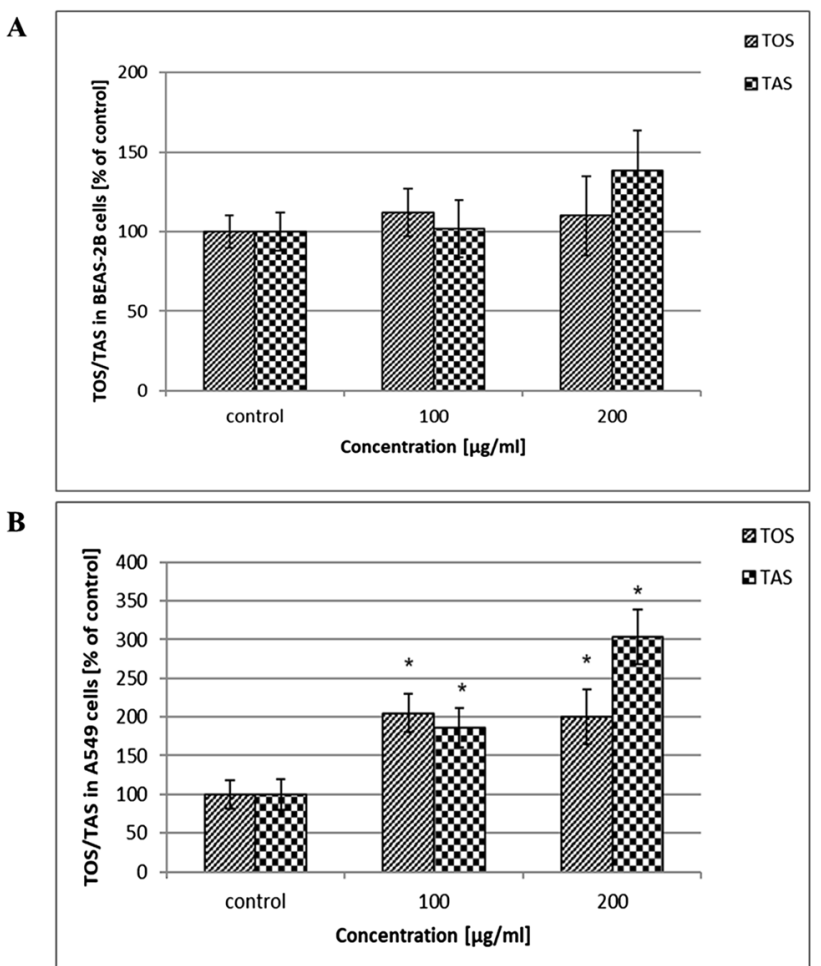

Fig. 5 Analysis of total oxidative status (TOS) and total antioxidative status (TAS) in cells treated with HNTs. The BEAS-2B cells (a) and A549 cells (b) were exposed to HNTs (100-200 $\mu \mathrm{g} / \mathrm{mL})$ for $24 \mathrm{~h}$. Data represent the mean \pm SD. *Significantly different from untreated control $(p<0.05)$

\section{Visualisation of morphological changes in exposed cells via HTM}

Treatment of BEAS-2B or A549 cells with HNTs at low doses 5 and $25 \mu \mathrm{g} / \mathrm{mL}$, caused morphological changes after 24 or $72 \mathrm{~h}$. The untreated cells (controls) had no alteration in cell morphology or any membrane damages (Fig. 7a, g). After 24 or $72 \mathrm{~h}$ of exposure, we observed cell contraction and changes in the size and shape in both BEAS-2B or A549 cells (Fig. 7 [l] b, d-e, i-k and Fig. 7 [Il] b, d, h, j, l). Also, we observed the loss of cell-cell contact in both treated cells compared with controls (Fig. 7). The result of the exposure of BEAS-2B or A549 cells to both doses of HNTs was also the characteristic cell surface folding (Fig. 7 [l] b-f, h and Fig. 7 [II] e-f, k) and cytoplasmic vacuolisation (Fig. 7 [l] b-f, h-1 and Fig. 7 [II] c, e-f, i-1). During the treatment, the degree of cytoplasmic vacuolisation was increased. After $72 \mathrm{~h}$ of exposure BEAS-2B cells to 5 and $25 \mu \mathrm{g} / \mathrm{mL}$ of HNTs, we observed peripheral arrangement of cell nuclei (Fig. $7[\mathrm{l}] \mathrm{h}$ ) and even increased number of nuclei (Fig. 7 [ll] 1), respectively. 


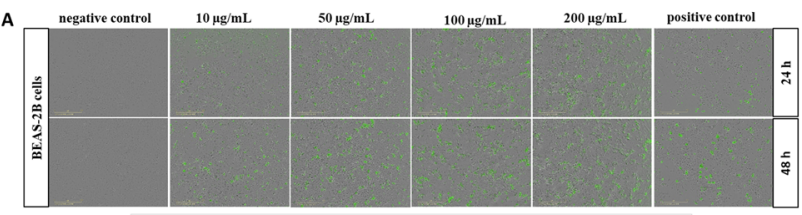

$=24 \mathrm{~h} \quad=48 \mathrm{sh}$

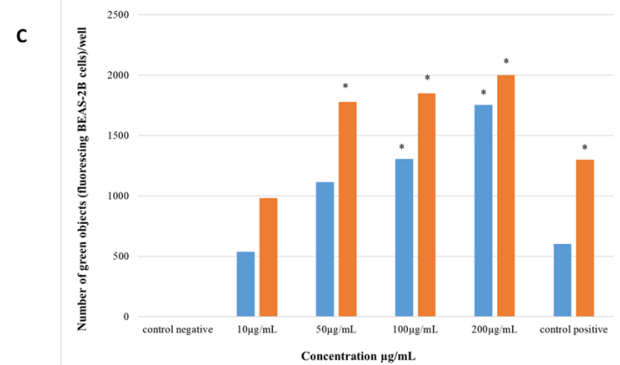

Fig. 6 Analysis of Caspase 3/7 activity in cells exposed to HNTs. BEAS-2B cells (a) or A549 cells (b) were treated with HNTs (10$200 \mu \mathrm{g} / \mathrm{mL}$ ) and staurosporine ( $37 \mathrm{nM}$ ) for 24 or $48 \mathrm{~h}$. Fluorescence images of over time were obtained with the use of image-based livecell analysis system (IncuCyte S3). A caspase 3/7 signal (green) rep-
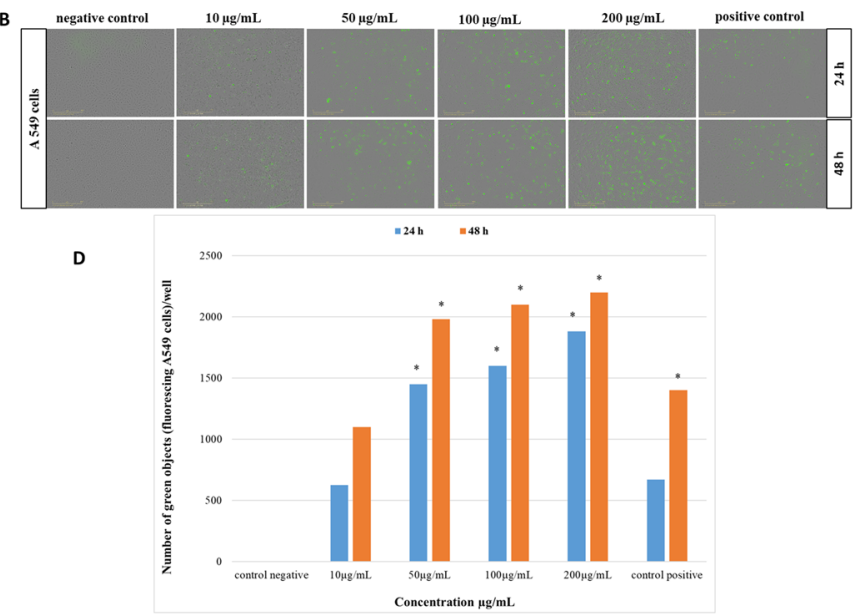

resents apoptotic cells. The representative pictures showed cells with a tenfold lens. c, d Graphic presentation of the caspase 3/7 activity analysis results in BEAS-2B cells and A549 cells, respectively. \pm SD not visible. *Significantly different from negative control $(p<0.05)$
I (BEAS-2B cells)

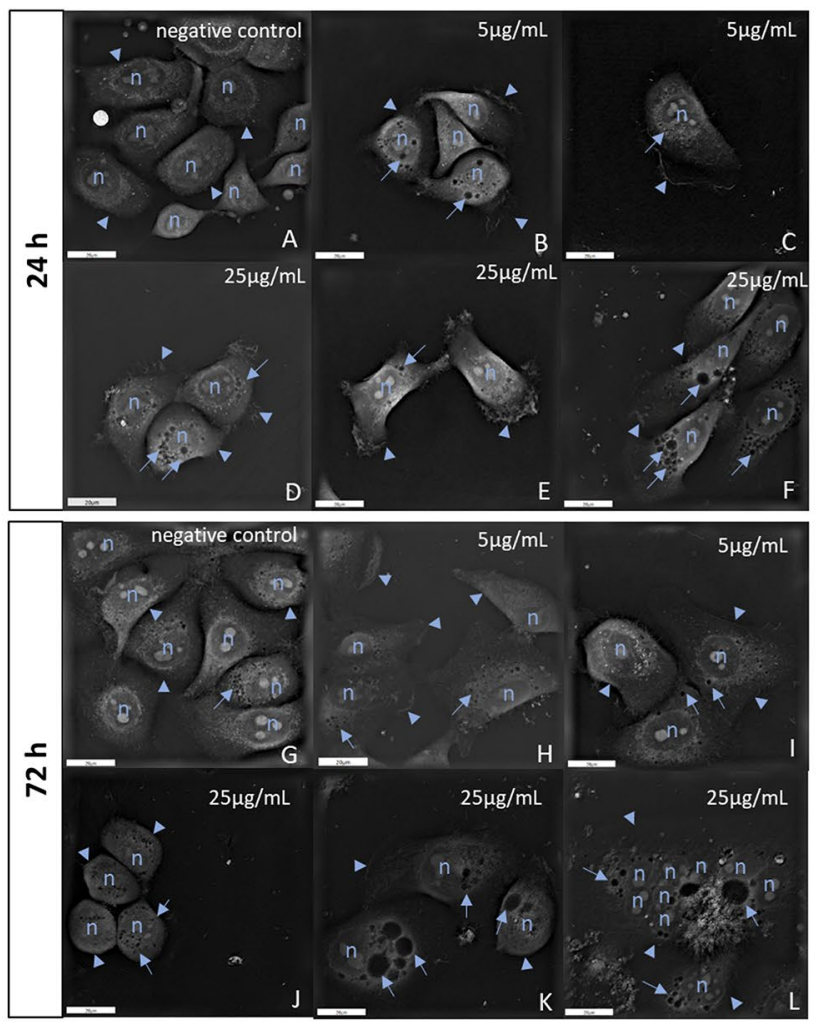

Fig. 7 Dose and time dependent morphological changes in cells after treatment with HNTs. Representative HTM images of BEAS-2B cells [l]) and A549 cells [II] incubated for 24 or $72 \mathrm{~h}$ with 5 or $25 \mu \mathrm{g} / \mathrm{mL}$ of HNTs. a, g Represent negative control (untreated cells) after 24 and $72 \mathrm{~h}$, respectively. b-f Represent cells after $24 \mathrm{~h}$ of treatment with
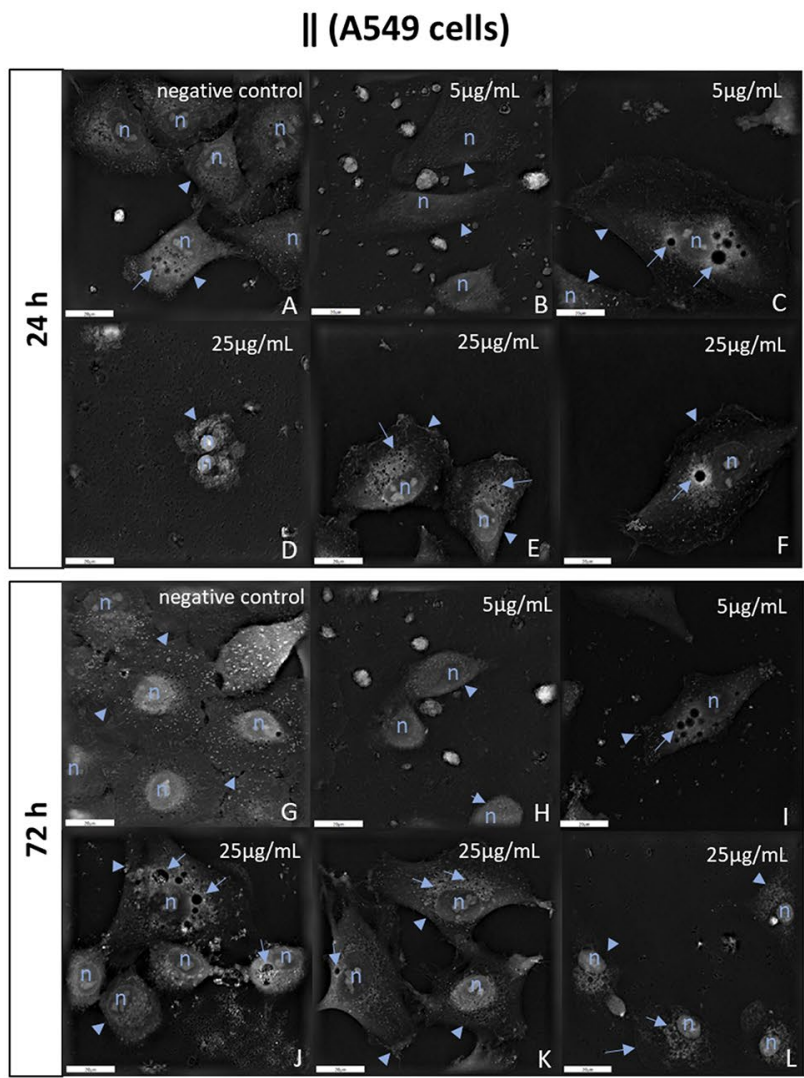

HNTs $5 \mu \mathrm{g} / \mathrm{mL}$ and $25 \mu \mathrm{g} / \mathrm{mL}$, respectively. h-l Represent cells after $72 \mathrm{~h}$ of exposure to HNTs $5 \mu \mathrm{g} / \mathrm{mL}$ and $25 \mu \mathrm{g} / \mathrm{mL}$, respectively. HTM images of cells showed (n) nuclei, numerous of cytoplasmic vacuoles (arrows) and cytoplasmic membrane (arrowheads). Description of changes is presented in the text. Scale bar $20 \mu \mathrm{m}$ 


\section{Discussion}

In recent years, the application nanomaterials has increased in many fields including industrial, medicinal and everyday objects. Although nanomaterials have potential benefits, their interaction with biological systems may cause unpredictable risk to human life. Halloysite is a natural nanosized tubular clay mineral that has many potentially important applications, such as inter alia environmental sciences, biomedicine, waste-water treatment, nanoelectronics, cosmetics, dye removal, fabrication of nanocomposites and forensic sciences [2]. Therefore, assessment of toxicity of HNTs is necessary to assess the human risk, especially in the working environment from a safety point of view. Our study focused on two important aspects. Firstly, we evaluated the cytotoxic effects in A549 cells and BEAS-2B cells after short( 24 or $72 \mathrm{~h}$ ) and long-term (7 days) treatment with HNTs. Secondly, we visualized the morphological changes in cells exposed to low doses of HNTs using HTM.

The cytotoxicity of nanoparticles (NPs) depends on their properties such as shape and particle size, agglomeration, surface charge and modification, mechanism of cellular uptake and toxicity response [22]. Characterisation of nanomaterials is the first step in the study of in vitro toxicity, especially evaluation of the "real-time" particles size and size distribution in the media used for cell culture. We characterized HNTs for size and particle size distribution using the NTA technique and primary size and morphology using SEM [23]. Our findings are in accordance with those of Gaaz et al. [24], we confirmed tubular morphology of HNTs with particles length and diameter circa above $1000 \mathrm{~nm}$ and $100 \mathrm{~nm}$, respectively (Fig. 1). The mode values evaluated after $24 \mathrm{~h}$ indicated that large share the particles in the F12K medium containing $10 \%$ FBS were below $100 \mathrm{~nm}$, which might have influenced the $\mathrm{IC}_{50}$ value. We also observed that after $24 \mathrm{~h}$, diameters of the particles were different in medium LHC-9 and F12K containing 10\% FBS and found to decrease over time (Fig. 2), which was in correlation with higher cytotoxicity observed after long time exposure (Fig. 3).

The toxicity tests used for screening of the NPs are mainly based on measuring the activity of living cells via mitochondrial dehydrogenase activity (MTT) [25], cell membrane integrity (NRU, trypan blue, propidium iodide) [26], apoptosis [27, 28], cytokine [29], oxidative stress [30, $31]$, ability to proliferate $[32,33]$ and DNA damages [34, 35]. Vergaro et al. [36] observed that the growth inhibition in MCF-7 and Hela cells exposed to HNTs was concentration dependent. They demonstrated that cell viability was $70 \%$ at doses of HNT up to $75 \mu \mathrm{g} / \mathrm{mL}$. The viability of both cells was decreased with the increase of HNTs concentration up to $1000 \mu \mathrm{g} / \mathrm{mL}$.
We also evaluated the cytotoxicity of HNTs using MTT assays. The $\mathrm{IC}_{50}$ value of HNTs in A549 cells and BEAS$2 \mathrm{~B}$ cells after $24 \mathrm{~h}$ of exposure was $152 \pm 6.4 \mu \mathrm{g} / \mathrm{mL}$ and $>400 \mu \mathrm{g} / \mathrm{mL}$, respectively. As shown in Fig. 2 , the diameter of HNTs decreases over time in media for both cells, which may influence the cytotoxic effect of HNTs. After $72 \mathrm{~h}$, we observed a decrease in $\mathrm{IC}_{50}$ values in A549 and BEAS$2 B$ cells to $49 \pm 3 \mu \mathrm{g} / \mathrm{mL}$ and $45.1 \pm 8 \mu \mathrm{g} / \mathrm{mL}$, respectively (Fig. 3a, b). Similarly, Verma et al. [37] also demonstrated that HNTs did not cause significant cytotoxic effect after $24 \mathrm{~h}$ of exposure in A549 cells at concentration up to $100 \mu \mathrm{g} /$ $\mathrm{mL}$. These results were obtained using cell-based automated high content screening in combination with real-time impedance sensing. Lai et al. [38] have evaluated HNTs toxicity in co-culture of intestinal cells (Caco-2/HT29-MTX) using LDH leakage, XTT assay and permeability assay. They did not observe toxic effect after $6 \mathrm{~h}$ of exposure to HNTs at doses $0-100 \mu \mathrm{g} / \mathrm{mL}$. Thus, the sensitivity to HNTs is dependent on dose, cell model and time of exposure.

Ahmed et al. [39] used one of the cell proliferation assays (WST-1) to examine the toxic potential of HNTs and showed that viability of hepatocellular carcinoma (HepG2) cells and colorectal carcinoma (HCT116) cells decreased in a dosedependent manner with cytostatic activity at $250-500 \mu \mathrm{g} / \mathrm{mL}$ and cytotoxicity at $1000 \mu \mathrm{g} / \mathrm{mL}$. Another method to examine cells ability to proliferate is clonogenic assay (CFEA). The advantage of this test is that it does not require any cellular dyes, which may interact with tested NPs and lead to invalid results [19, 40-42]. The CFEA assay allows to identify compounds which give rise to "mitotic death" as a result of DNA damage or apoptosis [19] and to assess the possible consequence of long-term exposure (7-10 days) at sub-lethal doses of NPs. We used CFEA to evaluate ability of A549 and BEAS-2B cells to form colony after 7 days of exposure to HNTs at doses $25-200 \mu \mathrm{g} / \mathrm{mL}$. A significant difference in SF value was observed in A549 after using HNTs in the dose range $100-200 \mu \mathrm{g} / \mathrm{mL}$. The cell proliferation was significantly decreased after exposure of BEAS-2B cells to HNTs at doses 25-200 $\mu \mathrm{g} / \mathrm{mL}$ (Fig. 4), which confirmed that toxicity of HNTs increased overtime of exposition.

It has been reported that NPs caused mitochondrial dysfunction by increasing levels of mitochondrial reactive oxygen species (ROS) [43, 44]. Because ROS are responsible for oxidative stress in cells, the determination of the total oxidative (TOS)/ total antioxidative (TAS) status is very important in toxicology research. Overproduction of ROS leads to change in cell motility, cytotoxicity, apoptosis, unregulated cell signalling, DNA damage and cancer initiation [45]. In our study, we evaluated TOS/TAS status after $24 \mathrm{~h}$ of exposure BEAS-2B cells or A549 cells to HNTs at doses 100-200 $\mu \mathrm{g} / \mathrm{mL}$. In treated BEAS-2B cells, we did not observe significant changes in the TOS/TAS level compared with control. However, 
we noticed a slight increase of TAS level after exposure cells to $200 \mu \mathrm{g} / \mathrm{mL}$ of HNTs (Fig. 5a). The TOS/TAS level in treated A549 cells was significantly dependent on the dose. After using HNTs at concentration $100 \mu \mathrm{g} / \mathrm{mL}$, we observed an increase in TOS, but it was accompanied by an increase in TAS. We observed noticeable differences in the TOS and TAS levels in A549 cells after treatment with $200 \mu \mathrm{g} / \mathrm{mL}$ of HNTs (Fig. 5b). It was worth to notice, that level of TAS was higher than that of TOS, which may indicate that cells have defence against oxidative stress mechanism [46], which is based on the system of antioxidants enzymes and non-enzymatic antioxidant substances capable of neutralising free radicals and preventing excess production of ROS.

Another cytotoxic effect of NPs is apoptosis resulting from activation of caspase [47]. Liu et al. [48] have analysed apoptosis in A549 cells exposed to HNTs at doses $10-200 \mu \mathrm{g} / \mathrm{mL}$ using TUNEL test. They showed a significant effect of HNTs on the number of apoptotic cells after $12 \mathrm{~h}$ of exposure at a concentration from $50 \mu \mathrm{g} / \mathrm{mL}$. In our study, we examined apoptosis in BEAS-2B cells or A549 cells using caspase $3 / 7$ assay after 24 or $48 \mathrm{~h}$ of exposure cells to HNTs (10-200 $\mu \mathrm{g} / \mathrm{mL})$. Despite HNTs did not significantly decrease cell viabilities after $24 \mathrm{~h}$ of exposure (Fig. 3), we observed an increase number of apoptotic cells in a dose- and time-dependent manner. Compare with negative control (untreated cells), HNTs $(50 \mu \mathrm{g} / \mathrm{mL})$ significantly affected the number of apoptotic A549 cells after 24 or $48 \mathrm{~h}$ (Fig. 6b, d). The caspase 3/7 activity in BEAS-2B cells significantly dependent on $24 \mathrm{~h}$ of exposure of $100 \mu \mathrm{g} / \mathrm{mL}$ of HNTs (Fig. 6a, c). Increase number of apoptotic BEAS-2B cells after $48 \mathrm{~h}$ of exposure on HNTs in doses from $50 \mu \mathrm{g} /$ $\mathrm{mL}$ was observed. Our result from caspase 3/7 assay and TOS/TAS assay showed that HNTs induced apoptosis independent of ROS.

Treatment of cells with NPs also caused morphological changes such as the formation of blebbed nuclei, numerous lipid droplets in the cytoplasm and increased numbers of mitochondria and cytoplasmic vacuoles containing nanoparticles [49-51]. To date, the changes in morphology of cells exposed to NPs were documented using optical microscopy, scanning electron microscopy (SEM) and transmission electron microscopy (TEM) [51-55]. SEM and TEM allow to obtain more detailed images, but require proper preparation of samples including trypsinisation, fixation or staining of cells which may affect cell morphology. To the best of our knowledge, this is the first study to use HTM for visualising cytotoxic effects of HNTs at low doses on cell morphology. It is worth to notice that this technique does not require any preparation of the sample.

We observed cell contraction in A549 and BEAS-2B cells exposed to HNTs at doses 5 and $25 \mu \mathrm{g} / \mathrm{mL}$ after 24 or $72 \mathrm{~h}$. It might be due to the loss of intracellular waters and electrolytes and thus resulted in changes in the size and shape of the cells (Fig. 7 [l] b, d-e, i-k and Fig. 7 [II] b, d, h, $\mathrm{j}, 1)$ in compare to control which had regular shape without any membrane damages (Fig. 7a, g).

During cells incubation, the loss of cell-cell contact was observed in both treated cells compared with control (Figs. 7). The characteristic of cell surface folding (Fig. 7 [l] b-f, h and Fig. 7 [ll] e, f, k) and cytoplasmic vacuolisation (Fig. 7 [l] b-f, h-l and Fig. 7 [ll] c, e-f, i-l) was also demonstrated after treated cells with both doses of HNTs. After $72 \mathrm{~h}$ of treatment BEAS-2B cells with $5 \mu \mathrm{g} / \mathrm{mL}$, we observed peripheral arrangement of cell nuclei (Fig. 7 [l] h). Furthermore, after $72 \mathrm{~h}$ of exposure BEAS-2B cells to $25 \mu \mathrm{g} / \mathrm{mL}$ of HNTs, we observed an increase in the number of nuclei (Fig. 7 [l] 1), which has been used by pathologists as a prognostic indicator of cancer [56]. Our results showed that doses of HNTs below $\mathrm{IC}_{50}$ caused morphological changes, that testify to adverse processes in the cells.

In conclusion, expanding application HNTs in many fields of industry or biomedicine and the associated increasing of unintentional exposure of humans to HNTs indicate that there is a need to estimate of its safety. Thus, a better understanding of HNTs cytotoxicity will allow to implement better protective measures for industrial workers. We presented that cytotoxicity of HNTs was dependent on dose, cell model and time of exposure. Furthermore, increase time of treatment with HNTs intensified the cytotoxic effects, which suggesting its potential chronic toxicity. HTM technology revealed that HNTs induce morphological changes in cells, which confirms the cytotoxic effect of HNTs even at low doses. Further studies with different cell models are recommended to assess the toxic effect of HNTs on the whole human body.

Acknowledgement The publication prepared on the results of the research task carried out under the statutory activities of the Central Institute for Labour Protection, National Research Institute (I-55).

\section{Compliance with ethical standards}

Conflict of interest The authors declare that they have no conflict of interest.

Open Access This article is licensed under a Creative Commons Attribution 4.0 International License, which permits use, sharing, adaptation, distribution and reproduction in any medium or format, as long as you give appropriate credit to the original author(s) and the source, provide a link to the Creative Commons licence, and indicate if changes were made. The images or other third party material in this article are included in the article's Creative Commons licence, unless indicated otherwise in a credit line to the material. If material is not included in the article's Creative Commons licence and your intended use is not permitted by statutory regulation or exceeds the permitted use, you will need to obtain permission directly from the copyright holder. To view a copy of this licence, visit http://creativecommons.org/licenses/by/4.0/. 


\section{References}

1. Koivisto AJ, Bluhme AB, Kling KI et al (2018) Occupational exposure during handling and loading of halloysite nanotubes-a case study of counting nanofibers. NanoImpact 10:153-160. https ://doi.org/10.1016/j.impact.2018.04.003

2. Satish S, Tharmavaram M, Rawtani D (2019) Halloysite nanotubes as a nature's boon for biomedical applications. Nanobiomedicine 6:1-16. https://doi.org/10.1177/1849543519863625

3. Chiriaco F, Conversano F, Sbenaglia EA, Casciaro S, Leporatti S, Lay-Ekuakille A (2014) Cytotoxicity measurements of Halloysite Nanotubes for nanomedicine applications. In: IEEE international symposium on medical measurements and applications (MeMeA), pp 1-4. https://doi.org/10.1109/MeMeA.2014.6860126

4. Kelly H, Deasy P, Ziaka E, Claffey N (2004) Formulation and preliminary in vivo dog studies of a novel drug delivery system for the treatment of periodontitis. Int J Pharm 274:167-183. https ://doi.org/10.1016/j.ijpharm.2004.01.019

5. Kommireddy D, Ichinose I, Lvov YM, Mills D (2005) Nanoparticle multilayer: surface modification for cell attachment and growth. J Biomed Nanotechnol 1:286-290. https://doi. org/10.1166/jbn.2005.046

6. Shi YF, Tian Z, Zhang Y, Shen HB, Jia NQ (2011) Functionalized halloysite nanotube-based carrier for intracellular delivery of antisense oligonucleotides. Nanoscale Res Lett 6:608-614. https ://doi.org/10.1186/1556-276X-6-608

7. Vergaro V, Lvov YM, Leporatti S (2012) Halloysite clay nanotubes for resveratrol delivery to cancer cells. Macromol Biosci 12:1265-1271. https://doi.org/10.1002/mabi.201200121

8. Hughes AD, Mattinson J, Powderly JD, Greene BT, King MR (2012) Rapid isolation of viable circulating tumor cells from patient blood samples. J Vis Exp 64:4248. https://doi. org $/ 10.3791 / 4248$

9. Kamble R, Ghag M, Gaikawad S, Panda BK (2012) Halloysite nanotubes and applications: a review. J Adv Sci Res 3:25-29

10. Rawtani D, Agrawal YK (2012) Multifarious applications of halloysite nanotubes: a review. Rev Adv Mater Sci 30:282-295

11. Yuan P, Tan D, Annabi-Bergaya F (2015) Properties and applications of halloysite nanotubes: recent research advances and future prospects. Appl Clay Sci 112-113:75-93. https://doi. org/10.1016/j.clay.2015.05.001

12. Zhang Y, Tang A, Yang H, Ouyang J (2016) Applications and interfaces of halloysite nanocomposites. Appl Clay Sci 119:8-17. https://doi.org/10.1016/j.clay.2015.06.034

13. Luo P, Zhao Y, Zhang B, Liu J, Yang Y, Liu J (2010) Study on the adsorption of Neutral Red from aqueous solution onto halloysite nanotubes. Water Res 44:1489-1497. https://doi.org/10.1016/j. watres.2009.10.042

14. Saber AT, Lamson JS, Jacobsen NR, Ravn-Haren G et al (2013) Particle-induced pulmonary acute phase response correlates with neutrophil influx linking inhaled particles and cardiovascular risk. PLoS ONE e69020:20138. https://doi.org/10.1371/journ al.pone. 0069020

15. Poulsen SS, Saber AT, Williams A et al (2015) MWCNTs of different physicochemical properties cause similar inflammatory responses, but differences in transcriptional and histological markers of fibrosis in mouse lungs. Toxicol Appl Pharmacol 284:16-32. https://doi.org/10.1016/j.taap.2014.12.011

16. Jaurand MC (2017) An overview on the safety of tubular clay minerals. Dev Clay Sci 7:485-508. https://doi.org/10.1016/B9780-08-100293-3.00020-0

17. Mosmann T (1983) Rapid colorimetric assay for cellular growth and survival: application to proliferation and cytotoxicity assays. J Immunol Methods 65:55-63. https://doi.org/10.1016/00221759(83)90303-4
18. Puck TT, Markus PI (1956) Action of X-rays on mammalian cells. J Exp Med 103:653-666. https://doi.org/10.1084/ jem.103.5.653

19. Herzog E, Casey A, Lyng FM, Chambers G, Byrne HJ, Davoren M (2007) A new approach to the toxicity testing of carbonbased nanomaterials-the clonogenic assay. Toxicol Lett 174:49 60. https://doi.org/10.1016/j.toxlet.2007.08.009

20. Franken N, Rodermond HM, Stap J, Haverman J, van Bree C (2006) Clonogenic assay of cells in virto. Nat Protoc 1:23152319. https://doi.org/10.1038/nprot.2006.339

21. Kruszewski M, Grądzka I, Bartłomierczyk T, Chwastowska J, Sommer S et al (2013) Oxidative DNA damage corresponds to the long term survival of human cells treated with silver nanoparticles. Toxicol Lett 219:151-159. https://doi.org/10.1016/j. toxlet.2013.03.006

22. Zhang XD, Wu D, Shen X, Chen J, Sun YM, Liu PX, Liang XJ (2012) Size-dependent radiosensitization of PEG-coated gold nanoparticles for cancer radiation therapy. Biomaterials 33:6408-6419. https://doi.org/10.1016/j.biomateria 1s.2012.05.047

23. Montes-Burgos I, Walczyk D, Hole P, Smith J, Lynch I, Dawson K (2010) Characterisation of nanoparticle size and state prior to nanotoxicological studies. J Nanopart Res 12:47-53. https://doi. org/10.1007/s11051-009-9774-z

24. Gaaz TS, Sulong AB, Akhtar MN, Raza MR (2015) Morphology and tensile properties of thermoplastic polyurethane-halloysite nanotube nanocomposites. Int J Automot Mech Eng 12:28442856. https://doi.org/10.15282/ijame.12.2015.4.0239

25. Lanone S, Rogerieux F, Geys J, Boczkowski J, Lacroix G, Dupont A, Maillot-Marechal E, Hoet P (2009) Comparative toxicity 27 manufactured nanomaterials in human alveolar epithelial and macrophage cell lines. Part Fibre Toxicol 6:14. https://doi. org/10.1186/1743-8977-6-14

26. Cho W-S, Duffin R, Bradley M et al (2013) Predictive value of in vitro assays depends on the mechanism of toxicity of metal oxide nanoparticles. Part Fibre Toxicol 10:55. https://doi. org/10.1186/1743-8977-10-55

27. Hillegass JM, Shukla A, Lathrop SA, MacPherson MB, Fukagawa NK, Mossman BT (2010) Assessing nanotoxicity in cells in vitro. Wiley Interdiscip Rev Nanomed Nanobiotechnol 2:219-231. https ://doi.org/10.1002/wnan.54

28. Lu X, Qian J, Zhou H et al (2011) In vitro cytotoxicity and induction of apoptosis by silica nanoparticles in human HepG2 hepatoma cells. Int J Nanomed 6:1889-1901. https://doi. org/10.2147/IJN.S24005

29. Sood A, Salih S, Roh D et al (2011) Signalling of DNA damage and cytokines across cell barriers exposed to nanoparticles depends on barrier thickness. Nat Nanotechnol 6:824-833. https ://doi.org/10.1038/nnano.2011.188

30. Hempel SL, Buettner GR, O'Malley YQ, Wessels DA, Flaherty DM (1999) Dihydrofluorescein diacetate is superior for detecting intracellular oxidants: comparison with 2,7-dichlorodihydrofluorescein diacetate, 5(and 6)-carboxy-2,7-dichlorodihydrofluorescein diacetate, and dihydrorhodamine 123. Free Radic Biol Med 27:146-159. https://doi.org/10.1016/s0891-5849(99)00061-1

31. Jakubowski W, Bartosz G (2000) 2,7-dichlorofluorescin oxidation and reactive oxygen species: what does it measure? Cell Biol Int 24:757-760. https://doi.org/10.1006/cbir.2000.0556

32. Souza TA, Franchi LP, Rosa LR, da Veiga MA, Takahashi CS (2016) Cytotoxicity and genotoxicity of silver nanoparticles of different sizes in CHO-K1 and CHO-XRS5 cell lines. Mutat Res Genet 795:70-83. https://doi.org/10.1016/j.mrgentox.2015.11.002

33. Bahadar H, Maqbool F, Niaz K, Abdollahi M (2016) Toxicity of nanoparticles and an overview of current experimental models. Iran Biomed J 20:1-11. https://doi.org/10.7508/ibj.2016.01.001 
34. Bhabra G, Sood A, Fisher B et al (2009) Nanoparticles can cause DNA damage across a cellular barrier. Nature Nanotech 4:876883. https://doi.org/10.1038/nnano.2009.313

35. Rim KT, Song SW, Kim HY (2013) Oxidative DNA damage from nanoparticle exposure and its application to workers' health: a literature review. Saf Health Work 4:177-186. https:// doi.org/10.1016/j.shaw.2013.07.006

36. Vergaro V, Abdullayev E, Lvov YM, Zeitoun A, Cingolani R, Rinaldi R, Leporatti S (2010) Cytocompatibility and uptake of Halloysite clay nanotubes. Biomacromol 11:820-826. https://doi. org/10.1021/bm9014446

37. Verma NK, Moore E, Blau W, Volkov Y, Babu PR (2012) Cytotoxicity evaluation of nanoclays in human epithelial cell line A549 using high content screening and real-time impedance analysis. J Nanopart Res 14:1137. https://doi.org/10.1007/s1105 1-012-1137-5

38. Lai X, Agarwal M, Lvov YM, Pachpande C, Varahramyan K, Witzmann FA (2013) Proteomic profiling of Halloysite clay nanotube exposure in intestinal cell co-culture. J Appl Toxicol 33:1316-1329. https://doi.org/10.1002/jat.2858

39. Ahmed FR, Shoaib MH, AzharM, Um SH, Yousuf RI, Hasmi S, Dar A (2015) In-vitro assessment of cytotoxicity of halloysite nanotubes against HepG2, HCT116 and human peripheral blood lymphocytes. Colloids Surf B 135:50-55. https://doi. org/10.1016/j.colsurfb.2015.07.021

40. Monteiro-Riviere NA, Nemanich RJ, Inman AO, Wang YY, Riviere JE (2005) Multi-walled carbon nanotube interactions with human epidermal keratinocytes. Toxicol Lett 155:377-384. https ://doi.org/10.1016/j.toxlet.2004.11.004

41. Casey A, Herzog E, Davoren M, Lyng FM, Byrne HJ, Chambers $G$ (2007) Spectroscopic analysis confirms the interactions between single walled carbon nanotubes and various dyes commonly used to assess cytotoxicity. Carbon 45:1425-1432. https:// doi.org/10.1016/j.carbon.2007.03.033

42. Ponti J, Colognato R, Rauscher H, Gioria S, Broggi F, Franchini F, Pascual C, Giudetti G, Rossi F (2010) Colony forming efficiency and microscopy analysis of multi-wall carbon nanotubes cell interaction. Toxicol Lett 197:29-37. https://doi.org/10.1016/j. toxlet.2010.04.018

43. Xia T, Kovochich M, Liong M, Zink JI, Nel AE (2008) Cationic polystyrene nanosphere toxicity depends on cell-specific endocytic and mitochondrial injury pathways. ACS Nano 1:85-96. https://doi.org/10.1021/nn700256c

44. Chen Q, Wang N, Zhu M, Lu J, Zhong H, Xue X, Guo S, Li M, Wei X, Tao Y, Yin H (2018) TiO2 nanoparticles cause mitochondrial dysfunction, activate inflammatory responses, and attenuate phagocytosis in macrophages: a proteomic and metabolomic insight. Redox Biol 15:266-276. https://doi.org/10.1016/j.redox 2017.12.011

45. Fu PP, Xia Q, Hwang HM, Ray PC, Yu H (2014) Mechanisms of nanotoxicity: generation of reactive oxygen species. J Food Drug Anal 22:64-75. https://doi.org/10.1016/j.jfda.2014.01.005
46. Lyakhovich VV, Vavilin VA, Zenkov NK, Menshchikova EB (2006) Active defense under oxidative stress. The antioxidant responsive element. Biochemistry-Moscow 71:962-974. https:// doi.org/10.1134/s0006297906090033

47. García de la Cadena S, Massieu L (2016) Caspases and their role in inflammation and ischemic neuronal death. Focus on caspase-12. Apoptosis 21:763-777. https://doi.org/10.1007/s1049 5-016-1247-0

48. Liu HY, Du L, Zhao YT, Tian WQ (2015) In vitro hemocompatibility and cytotoxicity evaluation of halloysite nanotubes for biomedical application. J Nanomater 2:1-9. https://doi. org/10.1155/2015/685323

49. Santimano MC, Martin A, Kowshik M, Sarkar A (2013) Zinc oxide nanoparticles cause morphological changes in human a549 cell line through alteration in the expression pattern of small GTPases at mRNA level. J Bionanosci 7:300-306. https://doi. org/10.1166/jbns.2013.1134

50. Valentini X, Deneufbourg P, Paci P, Rugira P, Laurent S, Frau A, Stanicki D, Ris L, Nonclercq D (2018) Morphological alterations induced by the exposure to $\mathrm{TiO} 2$ nanoparticles in primary cortical neuron cultures and in the brain of rats. Toxicol Rep 5:878-889. https://doi.org/10.1016/j.toxrep.2018.08.006

51. Sooklert K, Wongjarupong A, Cherdchom S, Wongjarupong N, Jindatip D, Phungnoi Y, Rojanathanes R, Sereemaspun A (2019) Molecular and morphological evidence of hepatotoxicity after silver nanoparticle exposure: a systematic review, in silico, and ultrastructure investigation. Toxicol Res 35:257-270. https://doi. org/10.5487/TR.2019.35.3.257

52. Schaeublin NM, Braydich-Stolle LK, Schrand AM, Miller JM, Hutchison J, Schlager JJ, Hussain SM (2011) Surface charge of gold nanoparticles mediates mechanism of toxicity. Nanoscale 3:410-420. https://doi.org/10.1039/c0nr00478b

53. Plascencia-Villa G, Starr CR, Armstrong LS, Ponce A, Jose-Yacaman M (2012) Imaging interactions of metal oxide nanoparticles with macrophage cells by ultra-high resolution scanning electron microscopy techniques. Integr Biol (Camb) 4:1358-1366. https ://doi.org/10.1039/c2ib20172k

54. Srikanth K, Pereira E, Duarte AC, Rao JV (2016) Evaluation of cytotoxicity, morphological alterations and oxidative stress in Chinook salmon cells exposed to copper oxide nanoparticles. Protoplasma 253:873-884. https://doi.org/10.1007/s00709-015-0849-7

55. Martin A, Sarkar A (2019) Epithelial to mesenchymal transition, eIF2 $\alpha$ phosphorylation and Hsp70 expression enable greater tolerance in A549 cells to TiO2. Sci Rep 9:436. https://doi. org/10.1038/s41598-018-36716-2

56. Weeks SE, Metge BJ, Samant RS (2019) The nucleolus: a central response hub for the stressors that drive cancer progression. Cell Mol Life Sci 76:4511-4524. https://doi.org/10.1007/s00018-01903231-0 